Geografia e Ordenamento do Território, Revista Electrónica

Centro de Estudos de Geografia e Ordenamento do Território

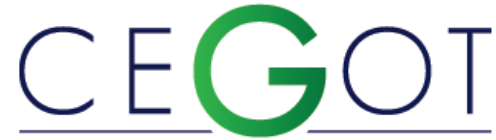

http://cegot.org

ISSN: 2182-1267

Centro de Estudos de Geografia e Ordenamento do Território

Smaniotto Costa, C.

Departamento de Urbanismo, Universidade Lusófona de Humanidades e Tecnologias

Lisboa, Portugal

smaniotto.consta@ulusofona.pt

Schmitz, R. M.

Colégio de Aplicação da UFRGS, Porto Alegre, Brasil rositams@hotmail.com

\title{
As modernas tecnologias de informação e comunicação e o espaço público Explorando as fronteiras de uma nova relação
}

Referência: Smaniotto Costa, C.; Schmitz, R. M. (2013). As modernas tecnologias de informação e comunicação e o espaço público, Explorando as fronteiras de uma nova relação. Revista de Geografia e Ordenamento do Território, n.ㅇ 3 (Junho). Centro de Estudos de Geografia e Ordenamento do Território. Pág. 197 a 229

\section{Resumo}

Este estudo discute a relação entre as tecnologias de mídia digital e a sua utilização no espaço público. Uma relação que não é nova, mas está crescendo a um ritmo acelerado e se transformando em um desafio para os especialistas em informática, paisagistas e arquitetos, bem como cientistas sociais. Ao apresentarmos e discutirmos alguns exemplos levantamos questões sobre o desenvolvimento urbano, agora sob a luz das novas tecnologias de mídia digital. A questão central é qual o contributo dessas tecnologias para transformar nossas cidades em ambientes mais sociais, em vez de apenas mais high-tech. Apresentamos e discutimos aqui uma série de exemplos de como as TICs interferem no uso e na produção do espaço público, com que resultados e riscos, e como elas se integram no novo conceito de sociedade virtual. 
Palavras-Chave: Tecnologia Móvel, Redes Sociais, Ambiente Urbano, Espaço Público, Mapeamento Comportamental, Design Urbano," Usuários do Espaço Público, Comportamento social, Estilo de Vida, Urban Games

\begin{abstract}
This study opens a discussion on the relationship between digital media technologies and their use in public spaces. A relationship that is not new but is growing at a rapid place, turning it into a very challenging topic for ICT experts, spatial designers and social scientists. The discussion backed by some examples raise questions about urban development, now under the light of new digital media technologies. The leading question: what is the contribution of ICT to transform our cities into more social environments, rather than just more high-tech? We present and discuss here a brief analysis of how ICTs affect the use of public space, what the risks are and how the uses fit into the concept of virtual society.
\end{abstract}

Keywords: Mobile Technology, Social Networks and Games, Urban Environment, Open Public Space, Urban Park, Place Design, Behavioural Mapping, Observation, Public Space Users, Social Behaviour, Life Style, Urban Games

\title{
1. Apresentação
}

Os computadores, as tecnologias de informação e comunicação, a telefonia móvel em constante evolução, com as mais diversas configurações e funções, estão paulatinamente interferindo e mudando o nosso modo de vida, seja no trabalho, na escola, no lazer, como no nosso relacionamento com outras pessoas ${ }^{1}$. Nunca houve tantas tecnologias que permitem comunicação instantânea, mesmo entre pessoas distantes. A internet tornou-se a maior rede de comunicação global.

Em 2002 Kenski fez uma análise interessante de como a internet em 10 anos interferiu em quase todos os campos da nossa vida. Essa análise tem hoje com certo valor histórico. KENSKI, Rafael. 'A internet, 10 anos que abalaram o mundo. Superinteressante, Setembro. http://super.abril.com.br/tecnologia/internet-10-anos-abalaram-mundo-443350.shtml, acessado em 27/06/2012 
Há muito tempo, o mundo digital deixou de ser algo fictício e baseado em artifícios irreais ou fantasiosos. Vivemos na era digital, na era da eletrônica, da transmissão instantânea de dados e supercomputadores com capacidade de processamento há algumas décadas inimagináveis. E isso, para Meyrowitz (1985) traz mudanças dramáticas na percepção de lugar e tempo, em nossa identidade, valores, ética, etiqueta e cultura. E ele segue afirmando: (em tradução livre) "Muitas coisas parecem permanecer as mesmas, no entanto, de alguma forma, tudo mudou".

O avanço das novas Tecnologias de Informação e Comunicação (TICs) nos leva também a refletir sobre o seu emprego onde as pessoas vivem e convivem: na cidade e em seus espaços. A cidade é espaço (político) por excelência do século XXI, ali acontecem as inovações. As TICs propulsionam a globalização que, por sua vez, envolve principalmente as cidades. Como é difícil prever as implicações, tanto a globalização quanto a informática tendem a ser vistas de forma negativa (Tomlinson 1999: 269), já que cada nova conquista, ao abrir horizontes, descortina também receios e medos. Não é surpreendente que na esfera social os efeitos da proliferação das TICs sejam considerados nocivos, já que eles ocorrem independentes de tempo e espaço. Como advertem Hampton \& Gupta (2008) e Souza \& Silva (2006), o contato social com a utilização de tecnologias móveis migra do espaço físico, já que elas permitem aos usuários estar constantemente conectados à internet (e através dela às redes sociais), mesmo quando estes se encontram ao ar livre. Alguns autores, como os citados em Graham \& Auguri (2007) \& Tomlinson (1999), argumentam que as cidades ocidentais estão em crise, econômica, ecológica, social e de identidade. Além disso, elas estariam presas entre a privatização e mercantilização (Graham \& Auguri 2007). Uma das consequências desta crise seria um suposto declínio na importância do espaço real, onde o medo crescente ao crime coibiria o uso do espaço público (ibid. \& Hampton et. al. 2008). Com os computadores nas casas, o espaço público perderia o seu significado. As pessoas passariam a viver principalmente em casa, na frente do computador, submetidas a uma avalanche de dados, viajando no ciberespaço e pelas autoestradas telemáticas, em uma realidade puramente virtual.

Esta previsão, ao menos até agora, não se realizou. Porém, com a informática, a internet, os telefones inteligentes e a globalização influenciando de várias formas o 
nosso quotidiano, estaríamos também mudando os nossos hábitos em relação ao uso do ambiente urbano. Algumas investigações têm abordado essas mudanças e sua influência nas relações sociais, poucas, no entanto, fazem referência direta ao espaço público. Meyrowitz (1985) e Hampton et. al (2009) referem sobre o comportamento social e as interações sociais sob a influência das TICs; Hampton \& Gupta (2008), sobre o uso de Wi-Fi em espaços públicos (e semipúblicos); Graham (2004), sobre a cidade virtual e o ciberespaço; Graham \& Auguri (2007) fazem ligações entre a cidade virtual, a crise no espaço público urbano e a polarização social no acesso a computadores e telemática; e Souza \& Silva (2006) declinam sobre a transição do espaço (virtual e real) em espaço híbrido com as tecnologias de telecomunicações móveis.

Os argumentos aqui apresentados seguem a linha de estudos que Graham (2004: 3) chama de "'urban ICT studies", e são baseados no pressuposto de que os espaços públicos são, e devem continuar a ser, os espaços de sociabilidade urbana e que a intersecção destes com os espaços virtuais pode trazer-lhes mais valia. O presente trabalho tem como fundamento os resultados de vários projetos de investigação (Greenkeys, Luda, Urge, B-Team ${ }^{2}$ ), financiados por diferentes programas de fomento da Comunidade Europeia. Mesmo tendo cada um deles uma temática diferente, o espaço urbano é o elo entre eles. Nestes projetos, levantam-se questões sobre o desenvolvimento urbano, agora retomadas e observadas sob o ângulo das novas tecnologias de informação e comunicação (TICS). Para nós, abre-se a questão se as TICS estão realmente mudando a percepção e a forma como usamos os espaços públicos. E, em caso positivo, quais seriam as consequências para aqueles que se ocupam da produção destes espaços.

Neste artigo, apresentamos e discutimos uma série de exemplos da presença das TICs no espaço público e como elas se integram no novo conceito de sociedade virtual. Não se trata de apresentar uma discussão conclusiva, mas sim de expor uma perspectiva exploratória, pois não se tem a pretensão de tratar todos os aspectos de forma

GreenKeys - Urban Green as Key for Sustainable Cities (www.greenkeys-project.net); LUDA - Large Urban distressed areas (www.luda-project.net), URGE - Urban Green and Environment (www.urge-project.ufz.de) e B-TEAM - Task Force for Brownfield Redevelopment (http://bteaminitiative.eu) 
abrangente. Pelo contrário, ele apresenta escolhas com a clara intenção de fomentar uma reflexão no que tange à simbiose do espaço cibernético com o urbano.

\section{O espaço virtual e o espaço real}

Inicialmente, há necessidade de delimitar os conceitos e seus componentes que serão usados a seguir, bem como colocá-los em relação com o objetivo deste trabalho - para melhor interpretar as inter-relações entre as TICs e o espaço urbano.

\subsection{As TICs, a mídia social e a economia criativa}

A internet, com o seu poder de alcance e a sua descentralização, tornou-se a maior rede de comunicação global, dando origem à mídia social. Como mídia social entendem-se os meios e tecnologias de comunicação digital, que permitem aos usuários criar e trocar ideias e conteúdos, individual ou coletivamente. Ela incorpora basicamente o que se encontra na rede, desde as mídias consideradas tradicionais, como jornais, revistas, rádio e TV, aos sites, blogs, fóruns de discussão, salas de bate-papo, etc. Além dessa convergência, a internet permite a interação e a integração dessas mídias. Essa propriedade é essencial, já que ela libera a informação de uma mão única - abolindo dualidades como da "TV para o telespectador, do jornal para o leitor, do rádio para o ouvinte $^{3 "}$. Os conteúdos agora são criados e postados de forma descentralizada e sem o controle editorial de grandes grupos ${ }^{4}$. Esses novos meios não só aceleraram o acesso à informação, mas também permitem que todos recebam e produzam informações ${ }^{5}$, alterando significativamente produção do conhecimento e do saber. Agora todos podem ser repórteres, escritores ou críticos de gastronomia. A mídia social, com os seus fóruns de debate, tornou-se também importante meio de formação de opinião, fonte de informação e veículo de marketing.

As TICs tornaram-se tão relevantes que formam hoje um importante segmento da economia mundial. Este segmento, que é também um modelo de negócios, é basicamente centrado na tecnologia da internet e nas suas facilidades de comunicação e

Mídias sociais: você está preparado? www.itu.com.br/conteudo/detalhe.asp?cod_conteudo=18911, acessado 13/07/2012

Wikipédia, http://pt.wikipedia.org/wiki/Mídias_sociais, acessado 22/06/2012

www.midiassociais.net, acessado 22/06/2012 
transferência de informações. As TICs estão intrinsecamente associadas à chamada indústria criativa, que também inclui entre outras artes e música. A economia criativa é importante no contexto estudado aqui, pois é essencialmente urbana, e está diretamente relacionada a atributos que podem igualmente definir o "urbano", como pluralidade (social, étnica, cultural, etc.), diversidade de usos, e a sua concentração em um determinado espaço ${ }^{6}$. Relevante é que as empresas criativas tendem a responder às preferências de seus funcionários, chamados por Florida (2002) de classe criativa, que atribuem grande valor à qualidade do seu ambiente de trabalho, de moradia e opções de lazer. Empresas da economia criativa são encontradas em cidades vibrantes e nas proximidades de espaços urbanos convidativos (Florida, 2002).

Um exemplo do atrelamento da economia criativa ao espaço urbano de qualidade pode ser visto na localização e criação de empresas do gênero em torno do High Line Park, em Nova lorque ${ }^{7}$. Uma destas empresas é a própria Google, que instalou o seu escritório regional a uma quadra do parque. A economia criativa é mais suscetível à qualidade de vida e amenidades urbanas. Esses dois fatores são decisivos na atração da força de trabalho, já que "talentosos" não só preferem, mas também podem se decidir a viver em cidades que são social, cultural e intelectualmente interessantes (Florida, 2002).

\subsection{Espaços públicos: o palco da vida urbana}

Como os termos espaços livres e espaços públicos vêm sendo usados nas mais variadas combinações, assim como para denominar os mais variados tipos de lugares, mesmo sem se aprofundar em uma discussão sobre conceitos filosóficos, sociais, simbólicos e políticos, o que extrapolaria o âmbito deste trabalho, gostaríamos de apontar brevemente algumas noções relevantes para a construção de espaços públicos como espaços sociais. E demarcar assim o objeto do presente trabalho.

Conceitualmente, a questão do espaço público urbano está no cerne de diversas disciplinas e de vários estudos, adicionando uma visão transversal à discussão sobre as

\footnotetext{
Para Florida (2002), três "Ts" formam o alicerce da economia criativa: tecnologia, talentos e tolerância. Esses são também, para ele, os fatores cruciais para a prosperidade das cidades no futuro. Florida, Richard. 'The Rise of the Creative Class...and how it's transforming work, leisure, community, \& everyday life'. Cambridge, 2002 McGeehan cita vários exemplos de como a economia local (e de maneira geral) está mudando no Meatpacking District, o bairro onde se encontra o parque. Veja: McGeehan, P.'The High Line Isn't Just a Sight to See; It's Also an Economic Dynamo'. The New York Times, June 5, 2011, www.nytimes.com/2011/, acessado 23/07/2012
} 
suas características, funções e benefícios. Entre esses, são relevantes no contexto deste estudo os seguintes autores: Ward Thompsom (2002 e 2007), que discursa sobre a sua estrutura e função, bem como sobre aspectos socioculturais. Gehl (1987) destaca a importância dos espaços públicos para as relações pessoais e coletivas, para a criação da identidade, e como torná-los mais atraentes para o uso social. Habermas (1990) discorre sobre a importância central do que é "público" e da participação democrática, Storck (2011 apud JACOBS, J. 1961) refere-se ao seu caráter cívico e político, Goheen (1998) e Smaniotto (2008) fazem referência como veículo de sociabilidade urbana e mediador das interações sociais, e Šuklje (2010), como um dos elementos essenciais na qualidade de vida em meio urbano. Santos (1988) ressalta o valor simbiótico destes, onde os elementos da história urbana de diferentes épocas convivem e interagem. Souza \& Silva (2006) vêem a necessidade de reconfigurar os espaços urbanos quando estes se tornam espaços híbridos. Esses autores, porém, se empenham em acentuar o caráter polissêmico e multifacetado dos espaços públicos, o que lhes atribui diversos significados e dimensões, mas que não existem isolados. De maneira pragmática, entenda-se espaço livre como um termo coletivo e, no seu sentido mais amplo, para definir todo aquele espaço não construído inserido no tecido urbano, isto é, com o predomínio de áreas desprovidas de edificações e estabelecido e mantido com determinado fim. Este fim pode ser desde propiciar a infraestrutura para a circulação, oferecer um local de convivência e recreação, ou preservar áreas pelos seus recursos paisagísticos e méritos ecológico-ambientais. Fica claro que esta definição abrange somente em parte os espaços urbanos não construídos. Por isso, temos que defini-los também pelo que eles não são. Por se tratar de espaços qualificados, não devemos confundi-los com as "sobras" da urbanização e do conjunto edificado, com espaços residuais da ocupação da paisagem, com aquelas áreas ociosas, à "espera" de uma "determinação". Isto não significa que muitos destes espaços não contribuam para a qualidade ambiental e ofereçam admiráveis opções para o lazer informal. Assim, os espaços livres assumem várias formas e abrangem tanto aqueles espaços criados pelo homem, como as ruas, as praças, os parques, os jardins, tanto aqueles (ainda) naturais ou já sob interferência humana, como áreas de proteção ambiental e da paisagem, cinturões verdes, bosques, florestas, terras utilizadas para a agricultura, corpos d'água, etc. (Smaniotto et. al. 2008). 
Com o mesmo pragmatismo, recorrendo à definição de Serpa (2004), definimos o espaço público como todo aquele espaço livre de uso comum e de posse coletiva, pertencente ao poder público. São os espaços de acesso irrestrito ${ }^{8}$, aos quais as pessoas vêm para realizar atividades individuais ou em grupos.

\subsection{As interações sociais e os espaços públicos}

Os espaços públicos são os lugares mais democráticos das cidades - aqui se encontram conhecidos e desconhecidos, aqui as diferentes camadas sociais se deparam umas com as outras, aqui se dão as relações formais e informais. A existência, a variedade e qualidade das ruas, praças e parques são de uma importância fundamental para que se realize a interação social, de dois ou mais indivíduos em contato, compartilhando atividades, como referem vários autores, entre eles Šuklje (2010) e Ward hompson (2002).

A produção e apropriação dos espaços públicos são um reflexo do estilo de vida urbano, e das pessoas que por fim são as que lhes dão vida, sujeitando os espaços públicos a processos sociais. A quantidade e a intensidade das interações estão diretamente ligadas à qualidade do espaço. Neste aspecto, Gehl (1987) é categórico: quanto mais propício for o espaço, mais as pessoas tendem a usá-lo e mais longas são as suas permanências, proporcionando maior contato entre os indivíduos. Por isso, os espaços públicos são considerados como possibilitadores das interações sociais.

Essa qualidade de possibilitador detém uma conotação positiva, mas há também que ser objetivo. A sociedade urbana é pluralista e apresenta finalidades e aspectos distintivos para a sua organização social. O ambiente urbano moderno, no seu conjunto, é tido como um dos responsáveis pelo aumento da segregação social, do isolamento e do pouco envolvimento de pessoas entre si (Gehl, 1987). Por esse motivo, faz-se necessário desmistificar a relação entre espaços públicos e interação social, relação esta vista com certo romantismo. Embora, segundo Whyte (1980), o que atrai as pessoas aos espaços públicos são as outras pessoas, estudos revelam que a grande maioria dos que usam os espaços públicos para as suas atividades de lazer não querem ser mais que meros

Mesmo que esse acesso irrestrito seja limitado, como é o caso de muitos parques ou jardins públicos no Brasil e em vários outros países, que em determinados períodos - principalmente à noite - são fechados. 
espectadores, não estando interessados em estabelecer contatos com estranhos. Para eles, vale a máxima: do ver e do ser visto. Isto significa passar o tempo de lazer de forma agradável e sem interferências ${ }^{9}$. De certa forma, cada usuário ou grupo "privatiza" o seu espaço (Serpa, 2007), criando o que Hampton (2008) denomina de casulo. Para ambos, o espaço público não é compartilhado, mas dividido e retalhado de forma individual ou coletiva entre os diferentes frequentadores. Embora invisíveis e passageiros, esses casulos isolam os indivíduos do contexto e reduzem a probabilidade de interações. Outro aspecto a ser mencionado é que as pessoas gostam de olhar as outras pessoas, mas não gostam de se sentir observadas ou encaradas (Whyte, 1980).

Estes fatos, porém, não negam o valor dos espaços públicos. Pelo contrário, reforçam a sua função como "lugar" para a construção dos casulos, como evidencia a Figura 1.

Figura 1: Será que o espaço público permanece como um lugar para a comunicação real? O Parque Georgengarten, em Hannover, em uma tarde ensolarada de domingo.

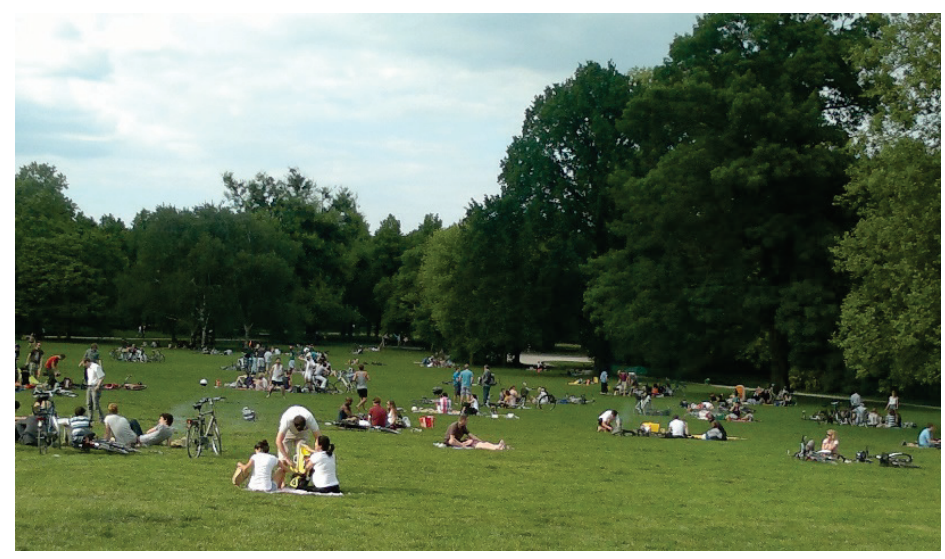

Portanto, o espaço público, como lugar de convívio, não se restringe ao espaço físico, capaz de ser medido e quantificado objetivamente, mas é também aquele espaço que apresenta a complexidade das relações sócio-espaciais, ao permitir a permanência, a comunicação e o contato face a face (Šuklje, 2010; Ward Thompson, 2002).

Ao abrigarem uma parcela importante do cotidiano da vida urbana, os espaços públicos merecem mais atenção nas políticas urbanas. A análise feita em 23 cidades europeias pelo projeto LUDA revelou que os espaços livres e, principalmente, os públicos,

\footnotetext{
Um estudo realizado em 2003 em Dresden (Alemanha) revelou que a grande maioria dos usuários dos parques da cidade, embora reconheça como positiva a possibilidade das relações sociais, não tem outros interesses além de uma simples conversa. Veja: Smaniotto Costa, C., Scherzer, C.; Sutter-Schurr, H. (2006) 'Tage im Grün - Nutzerwünsche und Nutzungsverhalten im öffentlichen Freiraum - eine Untersuchung in Dresden'. Stadt und Grün 11: 12-19
} 
constituem a estrutura mais constante dentro das cidades. Enquanto o uso e a arquitetura mudam, eles permanecem relativamente estáveis. Se os lugares permanecem os mesmos, as situações mudam (Santos, 1988). A história atribui diferentes papeis ao mesmo lugar. Como parte da sociedade, os espaços públicos ganham novas funções, que substituem ou são adicionadas às antigas. Este grau de estabilidade refere-se, portanto, a priori, a seu componente físico, enquanto o componente social é bastante volátil.

Esta estabilidade traz amplos benefícios ao ambiente urbano. Os espaços livres, e principalmente as áreas verdes, são usados para mensurar a qualidade de vida. Principalmente o índice de área verde por habitante ${ }^{10}$ é um indicador comumente usado para demonstrar a saúde urbana. Para Barberena (2011), os espaços livres são os elementos mais idôneos para avaliar o êxito e/ou a agonia de boa parte das políticas e ações públicas. Eles nos permitem avaliar a eficiência e competência da administração atual, bem como das anteriores, para gerar transformações sustentáveis das cidades, que resultem na sua revitalização e na melhora da qualidade de vida. A autora vai além, ao afirmar que, ao priorizar ou ignorar as necessidades básicas da população e das próprias cidades, investimentos em espaços públicos são o testemunho da vontade dos governos de honrar sua responsabilidade histórica para a construção das cidades, da cidadania e da democracia.

\section{A cidade real virtual}

A inclusão dos computadores e da internet na nossa vida quotidiana nos instiga e incentiva a navegar e interagir, estabelecendo uma forte correlação entre o mundo real e o virtual. De um lado, presenciamos cada vez mais uma extensão virtual da nossa vida real. Essa extensão, que é independente da localização das nossas ações, abre novas oportunidades de apropriação da cidade real e de seus espaços. Assim também na urbe contemporânea, temos que acrescentar essa nova escala virtual. E esta abre várias

Embora seja citada por diferentes autores, e supostamente feita pela OMS (Organização Mundial de Saúde), a recomendação de uma área verde de 8 a $9 \mathrm{~m}^{2}$ por habitante não pode ser constatada em literatura primária pelos autores. 
oportunidades para melhor compreender os espaços reais e entender os desafios a que estão submetidos.

\subsection{Interpretações da cidade real}

O processamento de informações via tecnologia digital também abre oportunidades interessantes para a compreensão e interpretação da cidade real. Na Internet há a disponibilização de uma série de arquivos fotográficos, tanto de caráter institucional como privado, como vistas panorâmicas de ruas e edifícios, e das mais diversas cidades. E isso não só facilita o acesso a informação, mas como também possibilita novas leituras da cidade. Alguns exemplos interessantes:

O projeto This is Now ${ }^{11}$ seleciona imagens de várias cidades carregadas no Instagram através do seu georreferenciamento, e, ao captar os movimentos de usuários nessas cidades, cria uma história atual e fluida do que acontece ali.

$\mathrm{O}$ atlas Geotaggers ${ }^{12}$ gera mapas de diferentes cidades ao redor do mundo a partir de fotos postadas nos portais Flickr e Picasa, acrescidas de seu georreferenciamento, considerando tanto imagens postadas por turistas como por residentes. Esses mapas revelam a concentração de motivos fotográficos e a frequência com que esses são fotografados. Assim podemos nos certificar da popularidade dos "cartões postais", bem como a sua densidade e distribuição dentro da malha urbana, como revela o mapa da cidade de Dresden (Figura 2).

http://now.jit.su, acessado 15/09/2012

12 www.flickr.com/photos/walkingsf/sets/72157623971287575/ 
Figura 2: Dresden: A paisagem urbana ao longo do Rio Elba é a área mais fotografada da cidade. As linhas azuis representam os fotógrafos locais, as vermelhas os turistas e as amarelas aqueles não possíveis de enquadrar nas categorias anteriores. Imagem: Via Flickr 2010

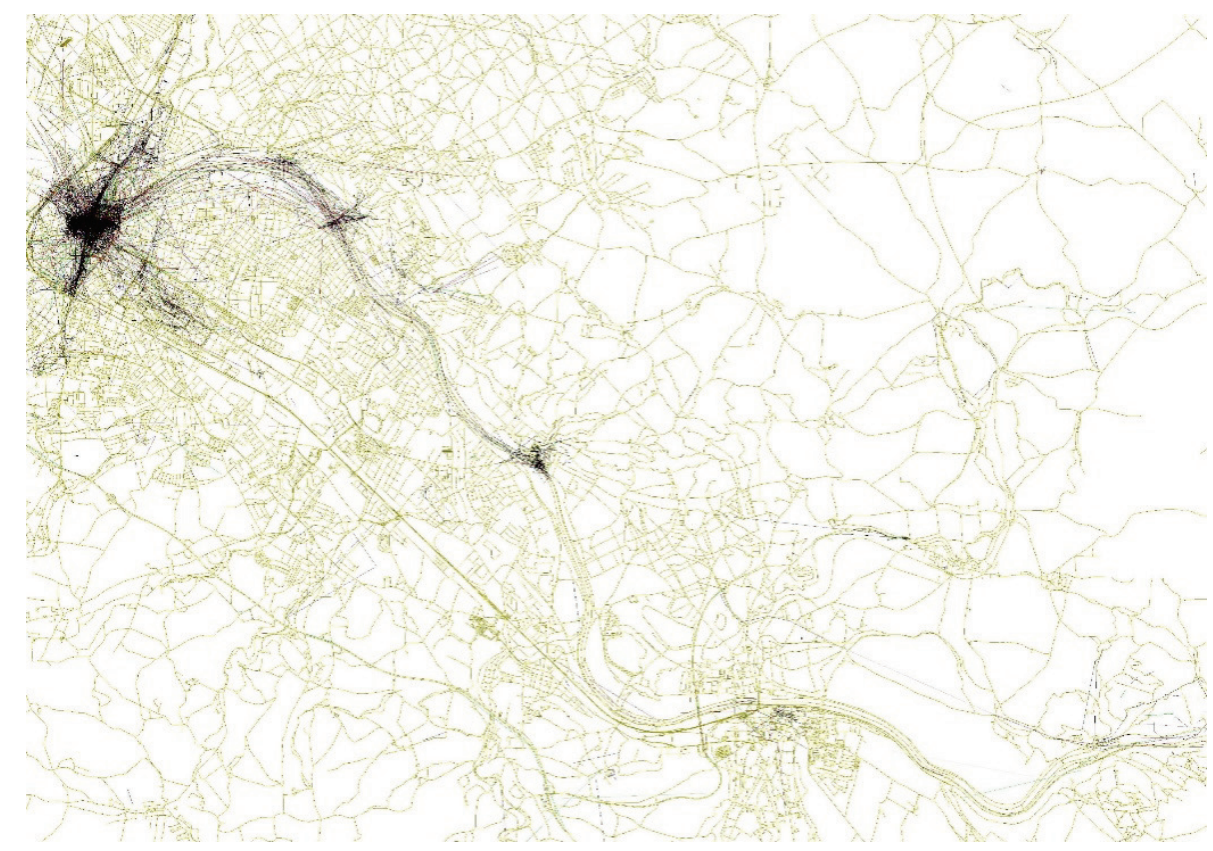

Mas uma cidade não se limita a seus cartões postais. É o que tenta revelar outro trabalho baseado no georreferenciamento. Com o argumento de que o visual e a essência (look and feel) de uma cidade não residem tanto nos seus poucos marcos famosos (como a Torre Eiffel para Paris), mas sim em um conjunto de elementos estilísticos, formado pelos detalhes visuais do cotidiano urbano, Doersch et. al. (2012) trabalham a partir de imagens do Google Street View em um método para filtrar e identificar a partir deste grande número de imagens o conjunto de tais elementos visuais, como calçamento, luminárias, sinais de trânsito, fachadas, janelas, terraços, etc. Esses elementos seriam as características distintivas de cada cidade. Ao todo foram mapeados elementos em 12 cidades. No artigo publicado, os autores, porém, se limitam a relatar o caso da capital francesa.

Ao analisar os elementos visuais distintivos, chegou-se à conclusão que as cidades europeias contam com muito mais características distintivas do que as norteamericanas, onde não há um estilo único dominante.

De Chant (2012) usa imagens de satélite do Google Maps para comprovar a teoria que coloca em estreita relação as diferenças sociais e a arborização urbana. Ao comparar imagens de bairros de diversas cidades, o autor demonstra que arborização e espaços verdes são mais frequentes naqueles bairros onde a população é mais abastada. $O$ verde 
urbano é assim um indicador de segregação sócio-espacial, e pode ser adicionado às desigualdades nas condições de moradia e de acesso a serviços públicos entre distintas classes sociais. As imagens usadas do Rio de Janeiro, por exemplo, a cidade brasileira presente no estudo, evidencia uma profunda diferença entre Ipanema (classe social alta) e a Rocinha (favela). O Rio de Janeiro, no entanto, não é um caso único. De Chant demonstra que em todas as cidades observadas existe essa diferença. Há dois fatores determinantes desta distinção. O primeiro refere-se ao poder aquisitivo: quanto mais alta for a sua renda, maior importância de uma pessoa dá à qualidade ambiental, podendo melhor escolher onde morar. O segundo fator é a presença do poder público nestes bairros, já que ele ali é mais pressionado a criar e manter estes espaços. Fica evidente que, enquanto o poder público age sob pressão em áreas onde a população o exige, negligencia e até ignora as áreas ocupadas pelas populações mais pobres. Estes dois fatores revelam uma grande incoerência, já que os mais pobres são os que, por não disporem de áreas privadas adequadas, mais precisam de espaços públicos, mas são provavelmente os menos capazes de reivindicá-los, ou de se verem atendidos em suas reivindicações.

\subsection{As viagens virtuais por paisagens reais}

Outro recurso para encontrar as cidades reais no ciberespaço é oferecido por alguns portais, que além do serviço de mapas e imagens, nos possibilitam fazer viagens virtuais por paisagens e cidades reais distantes. As diferenças entre esses serviços estão no tipo de imagem: umas transmitem imagens ao vivo e outras de fotomontagens. Para o primeiro grupo, podemos citar como exemplo o número crescente de webcams espalhadas pelas cidades que transmitem imagens ao vivo, e na sua maioria de locais públicos13. Não se devem confundir estas webcams com aquelas câmeras de videovigilância para controlar e monitorar o espaço público (vide Figura 3).

Alguns sites que oferecem imagens de várias cidades ao redor do globo: www.earthcam.com,

www.weatherimages.org/weathercams/world.html; para o Brasil: www.vejoaovivo.com.br, acessados em 11/05/2013. 
Figura 3: Em cada vez mais cidades, câmeras de vigilância monitoram os cidadãos. Exemplos da cidade de Danzig (Polônia) e Hannover (Alemanha).
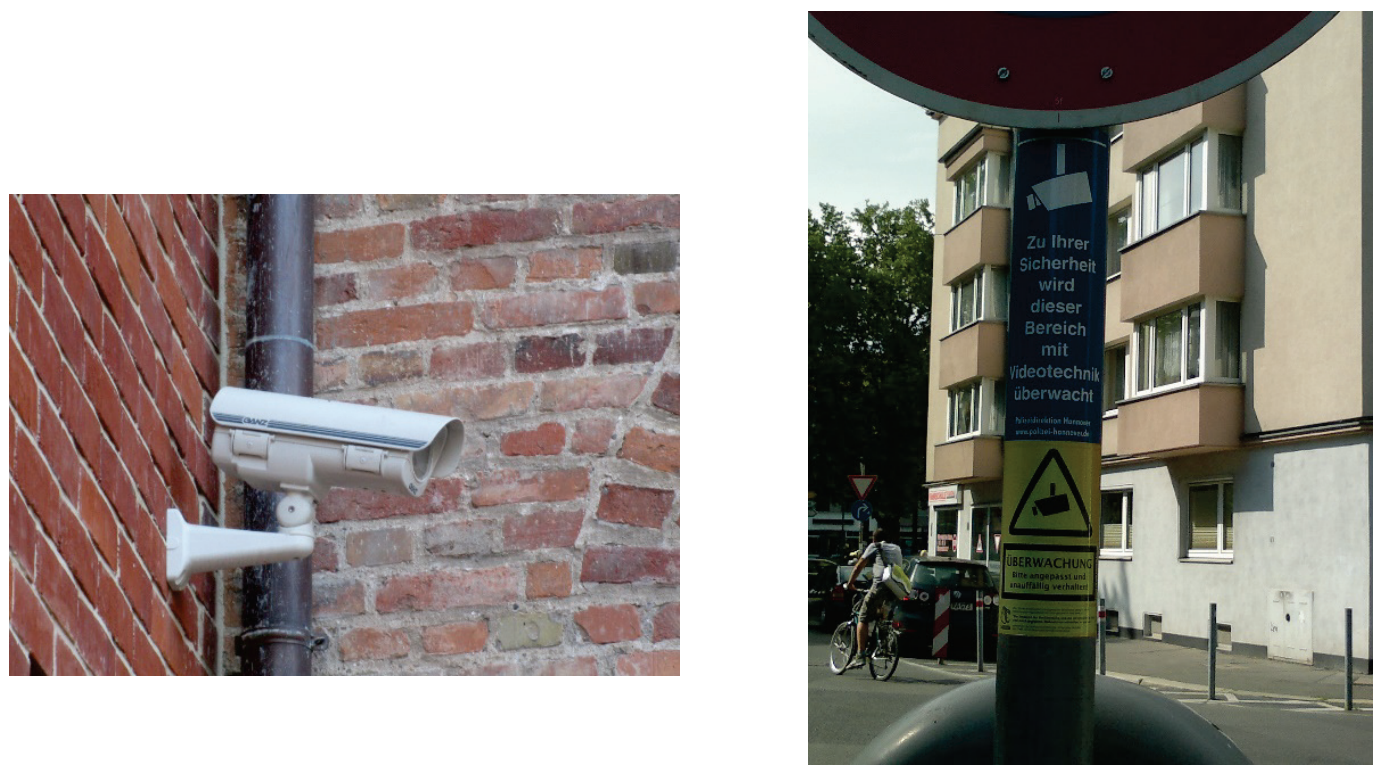

Os recursos do Google Maps (Street View) e do Google Earth disponibilizam vistas panorâmicas de algumas regiões do mundo também a partir do nível do solo. Com eles um internauta pode, por exemplo, realizar visitas virtuais pelas mais variadas cidades e paisagens ao redor do globo. Esta realidade virtual nos permite conhecer lugares distantes nos seus mínimos detalhes, sem deixarmos fisicamente o nosso ambiente, como passear pelo High Line Park, em Nova lorque ou pelo Hyde Park, em Londres.

Através destes passeios virtuais, as pessoas podem obter informações, visualizar e contemplar lugares que de outra forma não seria possível, bem como também se familiarizar com um local antes da visita real acontecer. Estes passeios virtuais estão longe de serem somente viagens imaginárias a lugares exóticos. Muitas vezes, cumprem objetivos práticos, como consultas a um destino real. Já em 2006, Horrigan \& Rainie provaram em seu estudo que $96,2 \%$ dos turistas norte-americanos usavam a internet não só como fonte de informação para viagens, mas também na sua organização, por exemplo, para a reserva de passagens e hotéis.

A essas interpretações digitais da cidade real, podemos contrapor outra tendência crescente, mas em outra direção, que pode ser observada em novas gerações de jogos de computador. Nesses jogos, a vida no mundo virtual não acontece mais em cidades fictícias, mas cidades reais funcionam como cenário do jogo, e em parte, em réplicas tridimensionais quase perfeitas. Com frequência, combina-se a fantasia com endereços 
reais, onde o jogador pode caminhar pelas ruas, mudar de apartamento e entrar em lojas. Em muitos casos, através da combinação do jogo com o comércio eletrônico, pode-se realmente adquirir produtos. Estes jogos usam a cidade real como uma metáfora, onde o mundo virtual é perfeito, sem congestionamentos e compartilhado só com "amigos". Uma rápida pesquisa no site em inglês de Wikipedia sob o tema "list of video games set in" fornece uma ampla lista de jogos, onde várias cidades reais servem de cenário.

\subsection{TICs e a possibilidade de interação e cooperação}

A possibilidade de interação e cooperação que as TICs oferecem para se criar "algo em conjunto" é amplamente utilizada pelo projeto internacional OpenStreetMap ${ }^{14}$, que, de forma semelhante a uma Wiki, visa criar um banco de dados geográficos capaz de gerar mapas cartográficos do mundo. Voluntários coletam dados in loco (como arruamento, estradas, ferrovias, rios, florestas, pontos interessantes e uso dos imóveis, etc.) e os colocam no site. O georreferenciamento destes dados permite a geração de mapas. A partir destes, cujo uso é gratuito e livre, podem ser criados outros mapas temáticos como: rede de ciclovias $^{15}$, de pontos turísticos e trilhas interessantes, rotas de navegação e outras informações úteis. Uma vantagem do OpenStreetMap é que, sendo ele um projeto cooperativo e sem objetivos financeiros, não tem, em consequência, o compromisso de enfocar somente "áreas economicamente interessantes". Isso fica claro quando se trata de locais como zonas rurais ou despovoadas, cuja informação digitall ainda é difícil de ser obtida. Na realidade, os mapas e o seu grau de detalhamento são determinados pelas contribuições dos voluntários. Para o mapeamento, realizam-se em vários locais os chamados "Mapping Weekends" ou "Mapping Parties ", para, de forma coletiva e sistemática, levantar e editar os dados de uma determinada área.

Outro aspecto da possibilidade de interação refere-se ao incipiente e-planning, que abre a possibilidade aos usuários de participarem via TICs no processo de planeamento e

\footnotetext{
14 www.openstreetmap.de. O vídeo postado em http://vimeo.com/38810476, acessado 15/07/2012, exemplifica detalhadamente como funciona a coleta e o georreferenciamento dos dados.

15 Por exemplo, site alemão de ciclovias www.naviki.org gera o seu sistema de navegação com base no openstreetmap, acessado $12 / 07 / 2012$
} 
produção da cidade. Esta possibilidade não vai, porém, ser foco aprofundado deste trabalho. Mas vale salientar que as TICs podem reforçar o diálogo entre atores e grupos envolvidos, além de proporcionar o uso de ferramentas inovadoras. Já existem algumas atividades no sentido de "experimentar" as possibilidades das TICs na produção dos espaços urbanos de forma mais criativa e com a participação da população local ${ }^{16}$.

Por outro lado, as novas TICs podem estimular a discussão com possíveis usuários, como comprovam Hampton \& Gupta (2008), que citam o caso de um bairro onde a introdução de uma lista de e-mails regular não só intensificou os laços sociais a nível local, mas também incentivou a participação pública no processo de desenvolvimento do bairro. Assim, ao integrar mais opiniões, as TICs podem tornar o processo de produção dos espaços urbanos mais participativo e democrático.

\section{As redes sociais, os blogs e o espaço público}

O ser humano é, por natureza, um ser social. Ele está constantemente envolvido em alguma atividade relacionada às outras pessoas. A internet, ao facilitar o compartilhamento de opiniões, ideias e experiências, aqui e agora e com o mundo todo, é uma ferramenta que cada vez mais usada nas relações sociais. As chamadas mídias sociais e os sites de relacionamentos, como o Facebook, Orkut, Linkedin, XING e outros, estão alterando substancialmente a comunicação, tanto na sociedade como nos modelos de negócio e mercados. E com uma taxa extremamente alta de inovação, as TICs devem continuar a se inserir na sociedade e nos negócios, com serviços e possibilidades ainda imprevisíveis. Mas também com incertezas e riscos, como a agressão eletrônica (cyber bullying) ${ }^{17}$, onde as TICS são usadas para realizar atos hostis ou violentos.

Ainda se discute se a internet e as redes sociais melhoraram ou pioraram as relações sociais. Há argumentos que sustentam as duas posições. Kaye \& Bryce (2012), por exemplo, contextualizam essas posições através dos jogos de videogame.

Por exemplo veja: www.themobilecity.nl/, acessado 23/08/2012

Sobre cyber bullying veja, por exemplo, o projeto financiado pele Comunidade Europeia.

https://sites.google.com/site/costis0801, acessado 12/08/2012 
Provavelmente, não se pode concluir lapidariamente; no entanto, no que se refere aos espaços públicos, o que se pode afirmar é que elas são um fato consumado. Portanto, é melhor se familiarizar e aprender a lidar com elas. Há vários exemplos de como a mídia social, como intermediária nas relações sociais, interfere na percepção e uso dos espaços públicos. Um dos seus grandes méritos é o de mobilizar pessoas e trazê-las pelos mais diversos motivos - ao ar livre. Vejamos alguns exemplos.

A rede social é, para um grande número de pessoas, uma extensão da vida, criando assim o elo entre o mundo real e o on-line. Talvez a miscigenação dos mundos real e digital seja uma das características da vida contemporânea. O próprio Facebook, a maior rede social de alcance global, criou um aplicativo para possibilitar ações no mundo real. Chamado de places $^{18}$, este aplicativo permite a um usuário divulgar aos seus "amigos e seguidores", através do botão check-in, onde ele atualmente se encontra no mundo real. Este serviço ajuda também a descobrir quem mais está por perto, bem como encontrar lojas, eventos e bares da moda nesta área.

O próprio Facebook analisou as informações de usuários disponibilizadas no places em 25 cidades, o que permitiu determinar os locais mais "sociais do mundo" ${ }^{19}$. São aqueles lugares mais mencionados pelos seus usuários na hora de marcar encontros ao vivo. Em seis destas cidades, aparecem espaços públicos (praças, parques, jardins e estradas) como os locais mais populares, como a Kurfürstendamm, em Berlim, ou a Times Square, em Nova lorque. Entretanto, em 19 das 25 cidades aparecem shoppings entre os 10 locais mais citados. Os resultados podem ser interpretados como uma espécie de barômetro de popularidade: eles indicam os pontos de encontro preferidos nestas cidades. Além disso, o estudo trouxe a confirmação de que o clima também desempenha um papel de destaque na vida dos internautas. Em cidades com clima mais quente, os encontros são marcados ao ar livre, por exemplo, no Parque Ibirapuera, o local de encontro preferido em São Paulo; e em cidades mais frias como Moscou, em bares e clubes.

\footnotetext{
18 Places está disponível somente em alguns paises. Embora negado pela rede, é bastante provável que através do places se possa rastrear e mapear os movimentos de um usuário, e coletar informações sobre o seu comportamento de compras. http://en.wikipedia.org/wiki/Facebook_features, acessado 23/06/2012 
Em Bruxelas, um grupo que reivindica espaços car-free, além de mais e melhores espaços públicos na capital belga, usa o Facebook para mobilizar as pessoas para participarem dos piqueniques realizados nas ruas da cidade ${ }^{20}$.

Outro modo de mobilizar pessoas pode ser visto nos blogs, que se transformaram na forma mais conhecida de interagir e mandar mensagens instantâneas. Ao permitir comentários, os blogs incentivam por sua vez a discussão. Os blogs têm dois componentes, que são suas propriedades essenciais: uma suposta liberdade de expressão, associada a um suposto anonimato. Um blogueiro, se não quiser, dificilmente será identificado, fato que, a princípio, é bom, já que graças a ele uma versão paralela on-line da vida é possível. Como o exemplo do Irã, citado por Röhlig (2010). Naquele país, com a sua sociedade condicionada às normas rígidas de conduta, blogar possibilitou a criação um mundo paralelo, onde jovens se encontram e se divertem, sem a separação por sexos e sem serem obrigados a se comportarem seguindo normas ditadas pelo regime. Lembrando que no Irã atual a Polícia da Moral (Moral Police) é a guardiã da moralidade pública, e sua tarefa é fazer cumprir não só o código de vestimenta islâmica, mas também combater uma suposta "invasão pela cultura ocidental" (ibid.). Outro exemplo pode ser visto nos movimentos revolucionários da chamada Primavera Árabe, que desde 2010 lutam por mais democracia e a derrubada de déspotas. E recentemente as demonstrações no Brasil.

Modernos meios de comunicação impulsionam esses movimentos, permitindo a difusão de informações, ideias e até imagens não oficiais e ao vivo de áreas de conflito (Storck 2011). Embora os modernos meios de comunicação digital sejam amplamente utilizados, esses movimentos, assim como certos atos e manifestações, precisam de um lugar real como cenário - reiterando a conexão entre as TICs e os espaços públicos.

O mundo paralelo virtual precisa do espaço real, pois ações que carecem da atenção pública, tais como demonstrações, greves, eventos desportivos ou mesmo o carnaval, exigem precisamente a proeminência que o espaço público pode oferecer. São acontecimentos que necessitam do imediatismo da encenação ao vivo, que pretendem transmitir a sensação de autenticidade ou que buscam o impacto da energia cinética de

\footnotetext{
20 www.facebook.com/PicnicTheStreets, acessado 04/08/2012
} 
uma massa posta em movimento. É neste contexto que a Praça Tahrir no Cairo se tornou conhecida em todo o mundo.

Figura 4: Depois de demonstrar no distrito bancário de Frankfurt, o Movimento Occupancy, que luta contra a desigualdade social e econômica, ocupa os gramados da Praça Friedrich na cidade alemã de Kassel durante a Documenta 13, uma das mais importantes exposições de arte contemporânea do mundo.
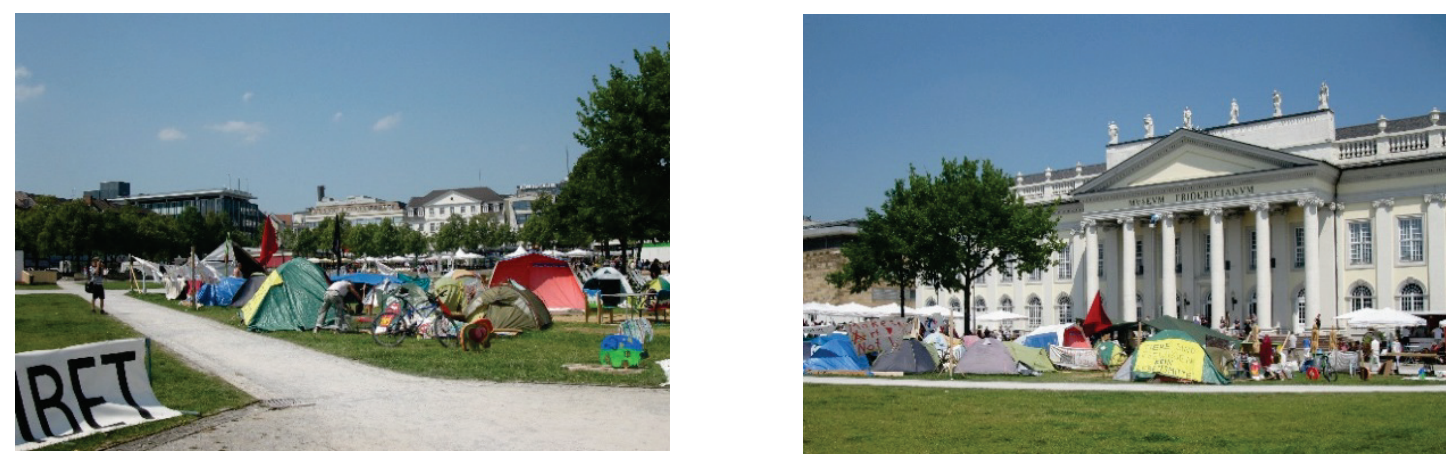

O uso do espaço público de forma "não convencional", com protestos e acampamentos, cria uma poderosa imagem midiática, como demonstra a Figura 4. Essas "ocupações" na realidade comprovam a alma essencial do espaço público como espaço democrático, capaz de incentivar a apropriação de acordo com as necessidades e anseios dos usuários. Essa apropriação, em sua essência, incorpora a ideia central do que é público.

Estes exemplos, na opinião dos autores, evidenciam claramente que os espaços públicos não se tornaram obsoletos, mas, ancorados nas tecnologias de informação e de comunicação, reafirmam seu papel como espaço democrático da urbe contemporânea.

\section{Rede sem fio (wireless) em parques e em espaços}

\section{públicos}

Segundo estudos, o acesso à internet é feito principalmente em casa e no trabalho ${ }^{21}$, mas em uma sociedade cada vez mais móvel parece ser essencial estar permanentemente conectado a recursos de informações e comunicações. As redes wireless ou $\mathrm{Wi-Fi}$ que permitem o acesso sem fio à internet, depois de conquistarem aeroportos, estações de comboio, hotéis, estão avançando pelas ruas, praças e parques. Com a popularização e padronização dos equipamentos, está cada vez mais fácil acessar

21 Nos EUA, 77\% da população utilizam a internet regularmente; destes $93 \%$ acessam de casa e 52\% do trabalho (HAMPTON et al 2008). Na China, esses números correspondem a $72,2 \%$ e 35,1\%, e 29,5\% acessam a internet de cafés (Wikipédia) 
a rede a partir de diferentes dispositivos, como notebooks, smartphones ou tablets. Para tanto, basta que o usuário se encontre dentro da área de abrangência de um ponto de acesso (conhecido por hotspot). A rede, ao permitir o acesso sem cabos à internet, confere aos internautas uma inquestionável flexibilidade geográfica.

Inicialmente, as redes wireless em espaços públicos foram instaladas e operadas por empresas de telefonia, que exigiam o pagamento pelo serviço. No entanto, é cada vez mais comum elas serem gratuitas e geridas por governos municipais. Assim, a disponibilização desta tecnologia e do seu acesso gratuito nas praças e parques é vista como um serviço público, o que é importante, considerando que a internet pode proporcionar uma grande democratização do conhecimento.

É crescente o número de cidades que oferecem hotspots em locais públicos (veja Figura 5, Figura 6 e Figura 7), entre elas Paris, Nova York e Londres. Outras planejam oferecer no futuro próximo este serviço, como Seul, que pretende ter cobertura total em 2014, e o Rio de Janeiro, que quer oferecer acesso gratuito e de alta velocidade para as Olimpíadas em 2016. Com a ajuda da própria internet, é bastante fácil encontrar os pontos de Wi-Fi nas mais diversas cidades. Aliás, esta informação já é padrão em guias de viagens on-line.

Figura 5: Parque Norte em Ljubljana, Eslovênia inaugurado em 2009. Projetado pelo atelier IN.KA.BI, sob o lema "Livros Unidos do Mundo", que criou portais multimídia, onde usuários podem ler (em monitores) e ouvir clássicos da literatura mundial na sua língua original. Saídas de USB permitem também ouvir músicas, o que é bastante usado por adolescentes. Havia também uma proposta de oferecer acesso à internet, mas até março de 2013 ele ainda não foi instalado. Fotos: IN.KA.BI 2010
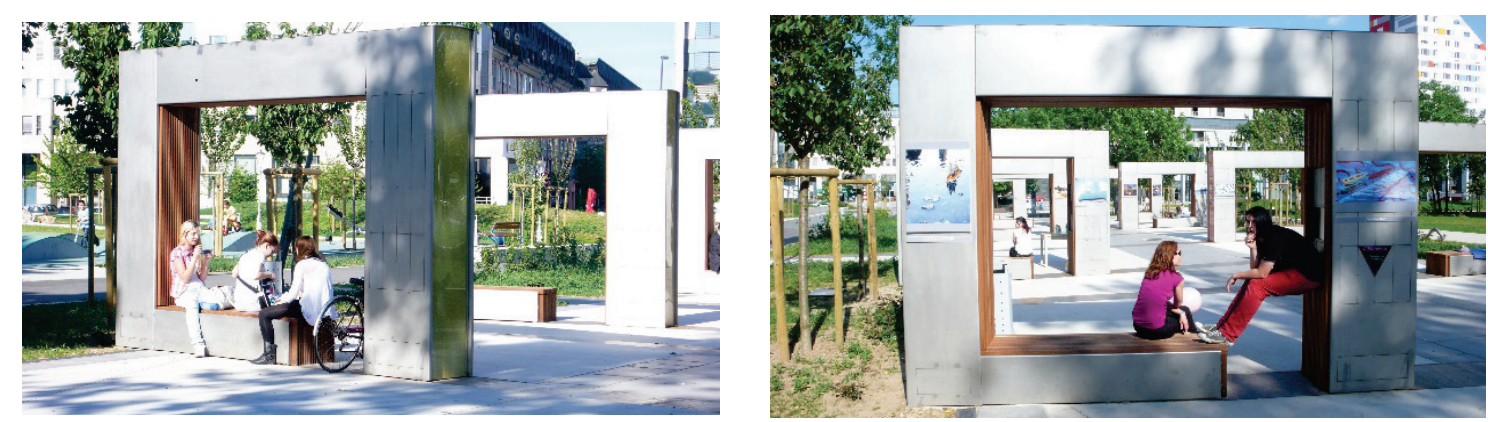
Figura 6: A Prefeitura de Santos (SP) oferece acesso gratuito à internet no calçadão da praia. Talvez estas plaquetas substituam aquelas de "não pise na grama".

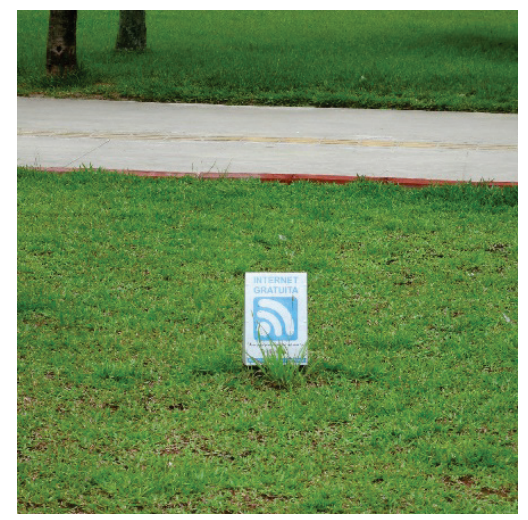

Figura 7: Justamente para o Campeonato Europeu de Futebol 2012, as cidades-sede na Polônia instalaram vários hotspots em espaços públicos. Sinalização pertinente indica as áreas com cobertura, como aqui na cidade de Poznan.

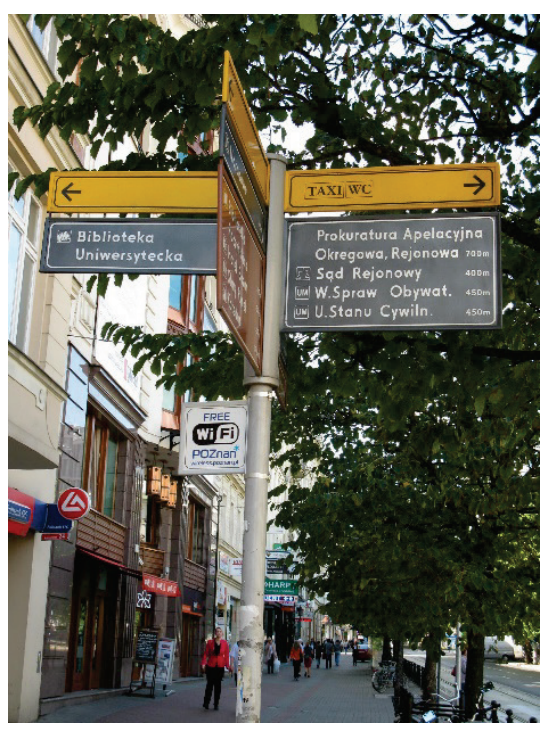

Os efeitos das redes sem fio em espaços públicos ainda não estão completamente investigados. Para Hampton et. al. (2008), elas têm implicações no planeamento urbano, na estrutura da sociedade e na natureza da própria democracia. É de se presumir que as pessoas, graças a mais essa facilidade, frequentem mais os espaços públicos, porém ainda como "lugar" de lazer e menos como de trabalho, embora essas novas tecnologias permitam flexibilidade, tanto em relação ao local quanto ao horário de acesso.

De maneira geral, no entanto, as redes wireless podem resultar em uma maior utilização dos espaços, trazendo mais pessoas ao ar livre, revitalizando lugares abandonados e melhorando a segurança do espaço público. E isso pode significar maior integração entre diferentes grupos, e maior diversidade, o que contribui para a redução das desigualdades sociais e para aumentar a coesão e tolerância de grupos com relação aos outros. Uma vez que há os usuários que transitam nos dois espaços, tanto nos reais 
quanto nos virtuais, eles podem contribuir para o discurso público, podendo estimular a ação política e contribuir para uma maior democracia. Ou também nenhum desses! A disponibilização do acesso à internet não significa por si só que o acesso à informação seja maior, nem que aumente a divulgação de ideias (Hampton et. al. 2008). Se as pessoas usarem os seus notebooks da mesma forma que usam atualmente os telefones celulares, é provável que o seu uso venha a acentuar a tendência de "privatizar" o espaço público. No caso dos telefones celulares, tanto para voz como para o envio de textos, as pessoas também criam os seus casulos.

A fim de maximizar os espaços públicos para usos sociais, e se tomarmos os indícios incipientes como confirmação de que as TICs, as redes wireless e os espaços públicos vão continuar se cruzando, talvez seja o caso de repensar considerações convencionais relacionadas ao desenho dos espaços e aos equipamentos de mobiliário urbano disponibilizados. Já existem algumas propostas e protótipos de mobiliário urbano com requisitos para facilitar a vida dos internautas, tais como fontes de energia para recarregar baterias, superfícies planas para os notebooks e sombras para permitir a visão dos displays. Em Setembro de 2012, a Prefeitura de Paris anunciou o projeto denominado Digital Break, do designer Mathieu Lehanneu como vencedor de um concurso para a criação de um mobiliário urbano próprio para acomodar os hotspots e oferecer condições mais propícias aos usuários ${ }^{22}$. Também em 2012 foi instalado no Parque Tašmajdan em Belgrado, capital da Sérvia, um novo elemento de mobiliário ${ }^{23}$ : um carregador de dispositivos tendo como fonte a energia solar.

\section{A informação digital no mundo real}

Também na transmissão de informações se percebem mudanças. A publicidade digital, com outdoors inteligentes, que com sua versatilidade permitem mostrar imagens em movimento, vídeos e músicas, estão substituindo os cartazes impressos, reabrindo a discussão sobre a privatização e mercantilização do espaço público.

\footnotetext{
www.mathieulehanneur.fr/works_gb.php, acessado 12/09/2012

www.archdaily.com.br/87521/black-tree-carregador-solar-publico-milos-milivojevic/
} 
Talvez o elemento visual mais óbvio da "conquista" da cidade real pelo mundo digital sejam os códigos QR (Quick Response Code), que estão se estabelecendo como uma interface entre o conteúdo digital e o espaço físico. Nos gráficos quadrados de QR estão armazenadas informações, que podem ser lidas com um aplicativo dos smartphone ou tablets. Através dos códigos QR, o usuário é levado a sites onde pode obter maiores informações. Como simples forma de conexão a outras informações, os códigos QR podem ser utilizados infinitamente.

Figura 8: O QR com estilo mosaico português instalado na Rua Garrett no Chiado de Lisboa. O QR leva ao site de informações turísticas da cidade, onde inclusive há um vídeo que documenta a construção do QR. Foto: A. Gago 2012

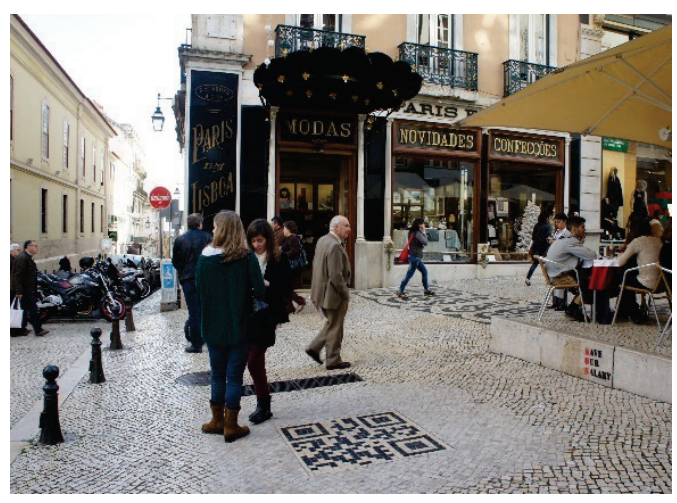

No meio urbano, os QR foram inicialmente empregados como charadas, mais tarde integrando arte e mídia de publicidade, e aos poucos estão sendo usados com novas finalidades utilitárias. Em 2011, a cidade alemã de Frankfurt equipou com códigos QR 23 obras de arte espalhadas pelos jardins da cidade ${ }^{24}$. Assim, os visitantes podem obter muito mais detalhes sobre essas obras do que seria possível em uma plaqueta impressa. A cidade de Hannover está incluindo nos seus cartazes e folhetos turísticos os códigos $Q R$, permitindo ao interessado obter informações atuais sobre a cidade e sobre eventos É evidente que fica em desvantagem quem não possui um aparelho apto para ler as informações codificadas em um QR.

Desde 2010, códigos QR são amplamente utilizados no icônico Central Park em Nova York. Lá cerca de 50 placas contendo os códigos QR, desenhados em forma de uma árvore e chamados de Parkode $^{25}$, encontram-se espalhados pelo parque, combinando informação e um jogo interativo, numa tentativa de atrair particularmente um público

www.kunst-im-oeffentlichen-raum-frankfurt.de, acessado em 23/07/2012

http://www.theworldpark.com/campaign, acessado em 22/04/2013 
mais jovem, que não costuma passar o tempo livre em parques. Os visitantes são instigados a desvendar segredos do parque, como locais de cenas de filmes famosos ou vistas do séc. XIX, e responder a questões relacionadas a esses locais. O parque se transforma assim em um gigantesco tabuleiro de jogo. Tanto meios de comunicação tradicionais como a mídia social foram usados para atrair pessoas para o evento.

Figura 9: Em Hannover foram instaladas as primeiras colunas de informação com monitores equipados com tela de toque, permitindo ao usuário navegar entre as descrições das atrações da cidade, os mapas e informações sobre eventos locais. A mesma informação pode ser encontrada on-line no site de turismo da cidade.

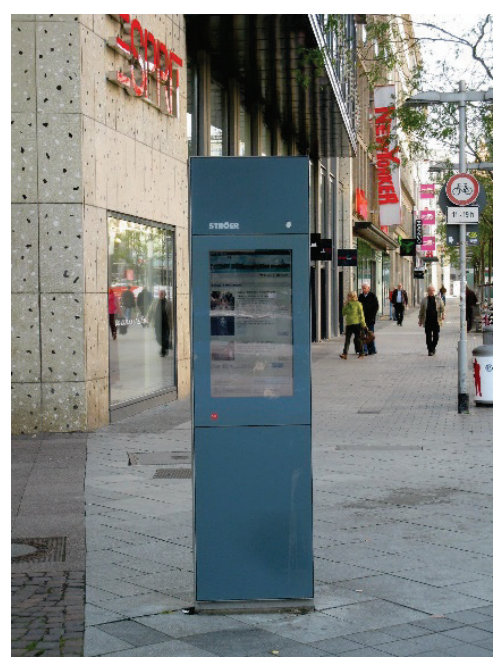

Figura 10: A informação digital ainda não tornou a "analógica" obsoleta. Talvez como forma de transição a justaposição das duas fontes de informação turística na cidade de Poznan (Polônia).

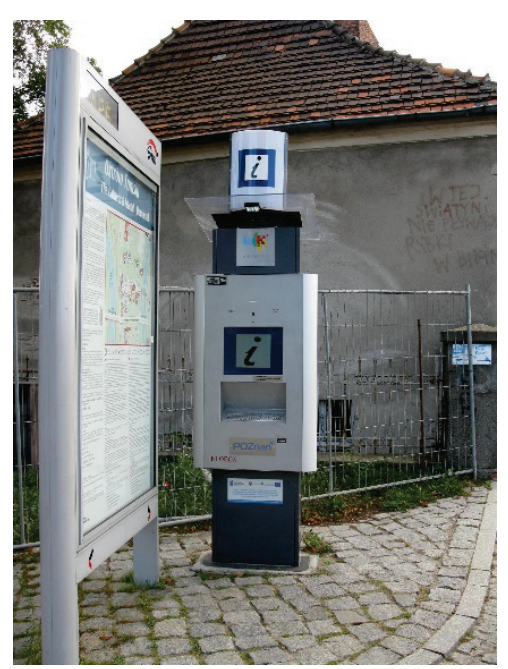

Outro exemplo de como os códigos QR são utilizados como veículos de informação vem de Paris. Lá, um coletivo criou o projeto Désordres Publics (desordem pública) ${ }^{26}$, que combina arte de rua e história não oficial da cidade. Os códigos QR foram montados em

26 www.raspouteam.org/QR, acessado 23/07/2012 
azulejos, e estes instalados em 20 lugares, nos quais ocorreram protestos e atos de desobediência civil, alguns culminando com a morte de manifestantes. Através da história contada por intermédio dos azulejos, tenta-se resgatar a memória desses acontecimentos, que aos poucos estavam caindo no esquecimento. A leitura dos códigos QR leva a um site, onde há informações sobre os fatos narrados, com imagens e vídeos, artigos de jornais e noticiários de televisão da época. É uma forma inovadora de manter na memória a luta de muitos cidadãos de Paris, e, fazendo uso de modernas tecnologias, conquistar novos interessados no assunto.

Outro domínio onde a cidade real e as TICs se encontram pode ser visto na arte de rua e nas expressões artísticas urbanas, com obras e instalações expostas em espaços públicos. Estas, porém, pelo seu caráter temporário, não foram consideradas neste trabalho.

\section{Jogos interativos e os urban games}

Com a propagação de novas tecnologias, cresce também o seu emprego em atividades de lazer e diversão. Principalmente a possibilidade de interação é amplamente utilizada nos chamados urban games, os jogos interativos nos quais o uso real dos espaços públicos faz parte do jogo. Os urban games tornam-se uma experiência interessante ao unir o computador com a oportunidade (e em alguns casos, até mesmo a exigência) de se realizar uma parte do jogo ao ar livre. Dois aspectos simpáticos residem na possibilidade de muitos destes jogos: o fato de poderem ser adequados às diferentes faixas etárias e aos níveis de experiência dos jogadores, e por serem jogados de forma quase despercebida pelo público em geral, conferindo-lhes certo fascínio, já que certo mistério faz parte destes jogos. Rawlinson \& Guaralda (2012) abordam de forma abrangente o papel de jogos e brincadeiras para o bem-estar individual e coletivo e Smaniotto \& Steinmeier (2012) refletem sobre os benefícios sociais e para a saúde física e mental que as atividades de diversão e lazer ao lar livre trazem. 
No site urbaneer ${ }^{27}$ são publicadas maneiras criativas para explorar o ambiente urbano, muitas c delas desenvolvidas como jogos. Entre os jogos urbanos já estabelecidos podem ser citados:

- Aqueles que reintroduzem o gênero aventura dos videogames, combinando o jogo on-line e ações nas ruas de uma cidade real. Exemplos: Can You See Me Now ou Uncle Roy All Around You, e a versão análoga do Pac-Man, o Pac-Manhattan, que utiliza a rede viária ortogonal de Nova lorque para recriar em escala humana o mais famoso dos videogames dos anos 1980.

- Geocaching (www.geocaching.com) é um jogo de caça ao tesouro ao ar livre. Os jogadores tentam localizar tesouros que são recipientes (chamados geocaches) escondidos em lugares públicos. Munidos de um receptor de GPS e usando coordenadas e pistas postadas no site os jogadores compartilham suas experiências on-line. E é importante ressaltar que quanto mais interessante for o esconderijo e mais bem elaboradas forem as pistas, mais cobiçados são esses tesouros (veja Figura 11). Como um exemplo de cunho educativo podemos citar uma série de Geocaching, organizado pela Empresa Municipal de Abastecimento de Água da cidade de Braunschweig (Alemanha), onde em 2012 mais de 2.000 geocaches já se encontravam escondidos, na maioria em parques e espaços verdes. Denominada Ciclos da água esta série gira em torno do tema água na cidade e leva os jogadores a diferentes estações onde se pode aprender mais sobre o processo de recolha, tratamento e distribuição de água potável e tratamento de esgotos. A intenção desta série é estimular o uso mais racional de água e a sua poupança ${ }^{28}$.

- Adote um gnomo (www.gnomeonthego.com) utiliza o georreferenciamento para identificar e informar sobre o paradeiro de gnomos, no caso adesivos magnéticos, que, colocados em automóveis alheios, viajam pelo mundo real.

http://urbaneer.net/, acessado em 10/05/2013

Braunschweig Versorgung AG: Braunschweiger Parks und Grünanlagen sind die Geocacher unterwegs. Revista BS.Energie,

Edição April 2011. 
Figura 11: Não só crianças e jovens podem ter grande prazer em sair em busca de um tesouro escondido ao ar livre. Este é um importante incentivo para uma vida mais ativa. Foto: G. Steinmeyer 2011

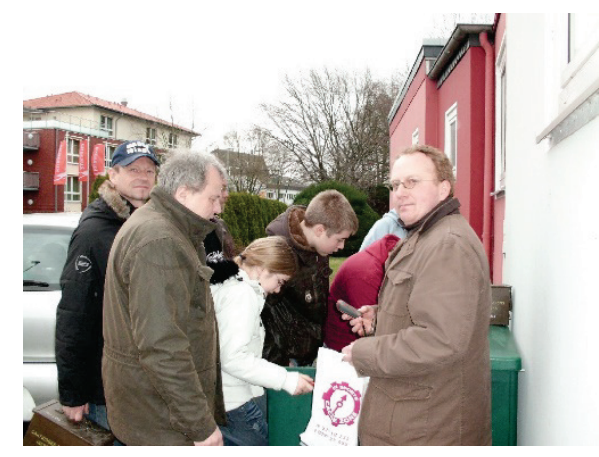

- Letterboxing (www.letterboxing.org). Semelhante ao geocaching, este jogo consiste em encontrar tesouros, aqui caixas de correio que contêm somente um carimbo e um livro de registros. Neste exemplo, o jogador registra a sua visita Com o seu carimbo e no seu livro com o carimbo encontrado. Interessante para muitos é a combinação do jogo com algo que já está quase desaparecido - o carimbo. Tanto o design dos carimbos quanto os esconderijos das letterbox os tornam cobiçados.

- Whereigo (www.wherigo.com) é um jogo interativo que deve ser baixado em um smartphone ou receptor de GPS. O jogo consiste em descobrir um destino final, através de dicas que vão sendo liberadas à medida que os jogadores alcançam etapas intermediárias. O interessante é que o jogo é montado a partir de histórias, que auxiliam o participante a desvendar os lugares aonde deve ir para receber novas instruções. A desvantagem é que muitas das histórias devem ser compradas, além da necessidade de se ter um aparelho adequado para jogar.

- Dead drops (www.deaddrops.com/) nasceu como uma arte-protesto e se diz uma "alternativa" para o cloud computing, com sua estrutura abstrata e obscura. O Dead drops oferece a oportunidade de qualquer um salvar dados (texto, imagens, filmes) offline e anonimamente em pen drives escondidos em lugares públicos.

Também os chamados urban sports oferecem uma atividade interessante, onde a própria cidade funciona como arena para ações de caráter mais desportivo. Os urban sports são geralmente uma derivação de esportes estabelecidos, e frequentemente aparecem novas ideais. Entre os "clássicos" podem ser citados o urban golf, jogado na cidade e sem percursos definidos, e o parkour, a habilidosa arte de se movimentar fazendo ginástica para superar os chamados obstáculos urbanos (escadarias, parapeitos, 
muros, edifícios). Como atualmente quase todos os praticantes dessas modalidades possuem telefone celular equipado com câmera, documentar a atividade através de fotos ou vídeos e publicá-los na internet se tornou parte integrante destes 'esportes'.

O denominador comum dos urban games vemos na aliança entre as mídias digitais e o espaço real. Se é on-line que encontros são combinados, rotas e regras esclarecidas, relatos sobre o sucesso (ou fracasso) postados, é no mundo real que as experiências acontecem. E nesta aliança é que está a mais valia destes jogos: ao explorar o potencial de lazer e de interação com o ambiente urbano, tirando as pessoas de suas casas e trazendo-as ao ar livre. Esta aliança tem dois componentes: primeiro, o valor social e cultural do jogo, e, segundo, o local de jogo no mundo real.

Por um lado, a mecânica destes jogos instiga o envolvimento com o meio ambiente ajudando os jogadores a criar laços e afeição com as suas cidades (Rawlinson \& Guaralda 2012). Assim, esses jogos podem ser catalisadores na formação de comportamento social, ajudando as pessoas a melhorarem sua capacidade de comunicação e habilidades sociais.

A simbiose entre mídia digital e jogos urbanos, por outro lado, levanta questões sobre a adequação da estrutura urbana para promover o bem-estar pessoal, bem como sobre o design dos espaços públicos para promover não só a comunicação e interação de pessoas no seu quotidiano (Souza \& Silva 2009), mas também para incentivar a sua exploração, mesmo de maneiras não previstas. A função educacional está presente ao combinar o fator aventura com a exploração de novos locais. Assim, se aprende a usufruir do espaço, a apreciar as suas qualidades, a se orientar, e em áreas verdes a apreciar e entender processos biológicos ou climático-ambientais (Smaniotto et.al. 2008). Ao usar as propriedades dos novos TICs, facilitando a troca de opiniões, ideias e experiências, os urban games contribuem para melhorar nossa capacidade de convívio e as nossas habilidades sociais.

Além desses usos lúdicos, existem ainda os jogos digitais chamados "sérios" (serious games) ou educativos, que não servem principal ou exclusivamente para o entretenimento, mas contem tais elementos para facilitar ou promover a transmissão de conhecimento. Em relação aos espaços públicos, as TICs e os jogos sérios abrem novas oportunidades para democratizar a produção desses espaços, ao possibilitarem contatos 
e facilitarem as interações e um maior diálogo em diferentes contextos. Essas qualidades possibilitam a criação de novos métodos e técnicas para a arquitetura dos espaços, bem como para a investigação sociológica sobre eles. Como exemplos podem ser vistos Click Your Way e Behaviour Mapping.

\section{Espaço público: Um desafio urbanístico, político e cultural}

Os exemplos apresentados neste trabalho comprovam que os celulares inteligentes, a internet e a globalização são parte integrante da vida contemporânea, com reflexos importantes na cidade real. As novas TICs e seu impacto sobre os espaços públicos não podem ser negados. Mas, à luz dos exemplos citados, faz-se necessário contestar certa tendência negativista, que quer ver nestes impactos o fim do espaço público. Esta tendência pressupõe um conceito conservador de espaço público, que tenta definir decisivamente suas funções, e não entende a mudança como sendo um elemento constitutivo do espaço urbano.

A heterogeneidade dos temas aqui tratados acentua que os espaços públicos e TICs se cruzam constantemente. As primeiras avaliações, embora ainda não conclusivas, já revelam certos referenciais e acrescentam uma nova dimensão ao debate sobre o papel dos espaços públicos. Os exemplos, ainda que esporádicos e incipientes, demonstram que nem o espaço público se tornou supérfluo, nem tampouco o mundo virtual se tornou um substituto do real. Mas que ambos se complementam. E nada mais inteligente do que tirar proveito desta interação e melhorar a qualidade dos espaços reais, para que eles continuem como palco e âncora do mundo virtual. Os espaços públicos, por ser uma das infraestruturas mais permanentes de uma cidade, podem servir como a espinha dorsal e estabilizante na volatilidade do mundo atual.

A cidade tem uma responsabilidade social e cultural com os espaços públicos e com as nossas necessidades diárias de sol, ar, descanso e contatos (Bannwart, 1996). Apenas quando os espaços públicos se tornarem atrativos, convidativos e seguros, as pessoas deixarão as suas casas. Talvez seja possível transformar o aficionado em computadores em um usuário menos sedentário, uma vez que a internet e as novas mídias oferecem uma excelente oportunidade de contatar pessoas, principalmente aos mais jovens. Os 
mesmos jogos que os prendem em casa podem atraí-los aos espaços reais e vinculá-los ao ar livre. Uma mudança de atitude, onde todos ganham.

Alterações estão ocorrendo, e as poucas evidências analisadas revelam também lacunas que uma investigação direcionada pode suprir. É importante incentivar a investigação sobre o uso das TICs e seus dispositivos em locais públicos, buscando encontrar respostas sobre as consequências dessas inovações para a produção destes espaços. E assim desvendar quais são as oportunidades de se equilibrar princípios de legibilidade e impessoalidade, privacidade e publicidade, segurança pessoal e vigilância mútua.

Melhorar a qualidade do ambiente urbano é uma tarefa interminável. Não existe cidade sustentável nem economia criativa, se não houver espaços urbanos saudáveis e convidativos. Esta frase parece clichê, e para muitos de fato é, mas ao observarmos muitas cidades, ela deixa de ser óbvia. Na cidade sustentável o adjetivo "público" não dever ser somente um apêndice, mas sim uma qualidade. Para que eles possam proporcionar uma variedade de benefícios e oportunidades para a interação social, cabe à administração pública reavaliar a política, no que se refere à qualidade, ao acesso e ao design destes espaços. Para isso, necessitamos de profissionais capacitados, paisagistas e arquitetos, que possam desenvolver e implementar ideias convincentes e bons espaços públicos, bem como políticos que priorizem a sua inserção na política urbana.

Os espaços urbanos construídos hoje são o legado para as futuras gerações: os implementamos, embora ainda não saibamos como a geração futura vai utilizá-los. Possivelmente, com as novas tecnologias, sejam criados os espaços públicos 2.0, com um update na estratégia da sua existência, pois mesmo um mundo cada vez mais virtual não vai dispensar a arquitetura real.

\section{Referências bibliográficas}

Bannwart, E. (1996). 'Virtuelle Räume und reale Erfahrung - im Gespräch mit Stefan Münker'. Telepolis. 27.02.1996, acessado 24/07/2012.

Barberena, L.(2011) 'Espacio Público y Gobernabilidad. Cuando la Anomia se convierte en Norma'. Plataforma Urbana, www.plataformaurbana.cl/archive/2011/11/24/espacio- 
publico-y-gobernabilidad-cuando-la-anomia-se-convierte-en-norma, acessado em $22 / 06 / 2012$.

De Chant, T. (2012) 'Urban trees reveal income inequality' -

http://persquaremile.com/2012/05/17/urban-trees-reveal-income-inequality, acessado em $10 / 08 / 2012$.

Doersch, C., Singh, S., Gupta, A., Sivic, J, Efros, A. (2012) 'What Makes Paris Look Like Paris?' ACM Transactions on Graphics, August 2012, 31, 3

http://graphics.cs.cmu.edu/projects/whatMakesParis/paris_sigg_reduced.pdf, acessado em 12.08.2012.

Enjolras B., Steen-Johnsen, K., Wollebæk, D. (2013) "How do social media change the conditions for civic and political mobilization?", acessado em 24/04/2013.

http://www.academia.edu/1353639.

Florida, R. (2002) 'The Rise of the Creative Class...and how it's transforming work, leisure, community, \& everyday life'. Cambridge: Kindle Edition.

Gehl, J (1987) "Life Between Buildings: Using Public Space. New York: Van Nostrand Reinhold

Goheen, P. G. (1998) "Public space and the geography of the modern city". Progress in Human Geography 22 (4): 479-496

Graham, S. (ed.) (2004) 'The Cybercities Reader'. London: Routledge.

Graham, S.; Auguri, A. (2007) 'Virtual Cities, Social Polarisation and the Crisis in Urban Public Space'. Journal of Urban Technology, 4 (1): 19-52

Habermas, J. (1990) "Strukturwandel der Öffentlichkeit". Frankfurt am Main: Suhrkamp. Hampton, K.; Livio, O.; Sessions, L. (2009). "The Social Life of Wireless Urban Spaces Internet Use, Social Networks, and the Public Realm". Journal of Communication, 60 (4): 701-722.

Hampton, K. N., Gupta, N. (2008) 'Community and Social Interaction in the Wireless City:

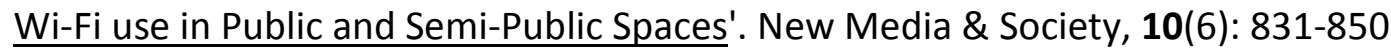


Horrigan, J.; Rainie, L. (2006) 'When Facing a Tough Decision, 60 Million Americans Now Seek the Internet's Help'. Pew Research CenterPublications, 19 de April 2006, http://pewresearch.org, acessado em 22/07/2012.

Kaye, L. K.; Bryce, J. (2012) 'Putting The "Fun Factor" Into Gaming: The Influence of Social Contexts on Experiences of Playing Videogames'. International Journal of Internet Science, 7 (1): 23-36.

Larsen, T. K. (2003). "ICT in urban planning". www.plan.auc.dk/ torben, acessado em 05/05/2013.

Meyrowitz, J. (1985) 'No Sense of Place: The Impact of Electronic Media on Social Behavior'. New York: Kindle Edition.

Rawlinson, C.; Guaralda, M. (2012) "Chaos and creativity of play: designing emotional engagement in public spaces". In Brassett,J. et. al (Eds.) Out of control: Proceedings of 8th International Design and Emotion Conference, University of the Arts London, UK, pp. 1-12 Accessed 24/04/2013. http://eprints.qut.edu.au/51313.

Röhlig, N. (2010). 'Iran 2.0 beta - Eine Nation fordert ihr Recht'. i-ref magazine, 08. Juli 2010, acessado em 22/06/2012.

Santos, M. (1988) 'Metamorfoses do Espaço Habitado'. São Paulo: Hucitec.

Serpa, A. (2007) 'O espaço público na cidade contemporânea'. São Paulo: Contexto.

Serpa, A. (2004) "Espaço público e acessibilidade: notas para uma abordagem geográfica". Revista GEOUSP - Espaço e Tempo, 15: 21-37.

Smaniotto Costa, C. (2012) "Kommunikationstechnik im öffentlichen Raum - Beispiele für neue Interaktionen". Stadt und Grün 11: 19-26.

Smaniotto Costa, C.; Steinmeier, G. (2012) 'A caça ao tesouro ao ar livre. Geocaching, uma oportunidade de lazer em espaços verdes'. Arquitextos, São Paulo, 12.143, Vitruvius, apr 2012 www.vitruvius.com.br/revistas/read/arquitextos/12.143/4332.

Smaniotto Costa, C. et. al. (Ed.) (2008) "GreenKeys @ your city' - A Guide for Urban Green Quality". Dresden: IOER. 
Souza e Silva, A. (2006) 'From cyber to hybrid: mobile technologies as interfaces of hybrid spaces'. Space \& Culture, 9 (3): 261-278.

Storck, M. (2011) "The Role of Social Media in Political Mobilisation: a Case Study of the January 2011 Egyptian Uprising". http://de.scribd.com/doc/132230246, acessado em 22/04/2013.

Šuklje Erjavec, I. (2010) "Designing an urban park as a contemporary user-friendly place" In Golicnik Marušić, B. \& Nikšič, M. (Eds) Human Cities - Celebrating Public Space, pp. 3951. Oostkamp: Stichting Kunstboek.

Tomlinson, J. (1999) 'Globalization and Culture'. University Of Chicago Press.

Ward Thompson, C. \& Travlou, P. (eds) (2007) "Open Space: People Space". Abingdon: Routledge.

Ward Thompson, C. (2002) "Urban Open Space in the 21st Century". Landscape and Urban Planning 60 (2): 59-72.

Whyte, W. H. (1980) 'The Social Life of Small Urban Spaces'. Washington: The Conservation Foundation. 